\title{
KONSEP PERLINDUNGAN HAK KONSTITUSIONAL PENYANDANG DISABILITAS DI INDONESIA
}

\author{
Arie Purnomosidi \\ Fakultas Hukum Universitas Surakarta \\ Korespondensi: arie.poernomosidi@gmail.com
}

\begin{abstract}
Abstrak
Berbicara tentang hak konstitusional, berarti membicarakan tentang hak dasar manusia yang dimuat dalam konstitusi. Hak-hak yang diatur dalam konstitusi merupakan batas yang tidak bisa dilanggar oleh penyelenggara Negara dalam menjalankan kekuasaan Negara, baik sebagai hak warga Negara atau hak asasi. Dalam UUD 1945 hak-hak yang secara tegas disebut sebagai hak asasi manusia yaitu sebagaimana termuat dalam Bab XA UUD 1945. Salah satu hak konstitusional yang diatur dalam UUD NRI 1945 adalah hak konsitutisional penyandang disabilitas. Hak konstitusional penyandang disabilitas ini perlu untuk diatur baik dalam konstitusi maupun di dalam undang-undang yang bertujuan bukan hanya untuk menjamin pemenuhan hak dan kebutuhan para penyandang disabilitas, tetapi juga memberikan tanggung jawab pada pemerintah dan masyarakat untuk lebih berperan aktif dalam memberikan perlindungan terhadap harkat dan martabat para penyandang disabilitas.
\end{abstract}

Kata kunci: Perlindungan Hukum; Hak Konstitusional; Penyandang Disabilitas.

\begin{abstract}
Discourse on constitutional rights includes the discussion about basic human rights as contained in the constitution. The rights stipulated in the constitution, both citizens as well as human rights, provide a limit which can not be infringed by the state administrators in performing their authority. In the Constitution of 1945 the rights which are explicitly referred to as human rights are contained in Chapter XA. One of the constitutional rights set forth in the constitution is the constitutional rights of persons with disabilities. The constitutional rights of persons with disabilities need to be regulated in the constitution as well as in legislation not only to ensure the fulfillment of the rights and needs of persons with disabilities, but also to provide the basis for the responsibility of the government and the community to be more active in providing protection of the dignity of persons with disabilities.
\end{abstract}

Keywords: Legal Protection; Constitutional Rights; People with Disabilities 


\section{PENDAHULUAN}

Pasal 1 ayat (3) Undang-Undang Dasar Negara Republik Indonesia Tahun 1945 (UUD NRI 1945) menyebutkan bahwa Negara Indonesia adalah negara hukum. Konsekuensi dari Pasal 1 ayat (3) UUD NRI 1945 tersebut bahwa dalam negara Indonesia hukum ditempatkan dalam kedudukan tertinggi dalam rangka penyelenggaraan negara. Dalam penyelenggaraan negara tersebut, hukum dibentuk kedalam suatu konstitusi, yang dalam hal ini adalah UUD 1945. Menurut J.G. Steenbeek, konstitusi sebagai aturan dasar tertinggi dalam suatu negara minimal memuat tiga hal pokok yaitu: (1) adanya jaminan dan penghormatan terhadap Hak asasi manusia dan warga negaranya; (2) ditetapkannya susunan kenegaraan suatu negara yang bersifat fundamental; dan (3) adanya pembagian dan pembatasan tugas ketatanegaraan yang juga bersifat fundamental. ${ }^{1}$
Perlindungan dan pemenuhan hak asasi manusia maupun hak warga negara menjadi inti dari konsepsi negara hukum. Oleh karena itu, segala norma hukum yang menjadi dasar penyelenggaraan negara harus diorientasikan kepada perlindungan dan pemenuhan HAM dan hak warga negara. ${ }^{2}$ Dalam praktik penyelenggaraan negara hukum, diperlukan adanya instrumen dan institusi hukum untuk menjaga dan menjamin perlindungan dan pemenuhan hak warga negara. Instrumen dan institusi hukum inilah yang menjadi ciri dari negara hukum, yang berkembang baik dalam tradisi hukum civil law dengan konsep rechtsstaat ${ }^{3}$ maupun dalam tradisi hukum common law dengan konsep the rule of law. ${ }^{4}$

Hak-hak yang diatur dalam konstitusi merupakan batas yang tidak bisa dilanggar oleh penyelenggara negara dalam menjalankan kekuasaan negara, baik sebagai hak warga negara atau hak asasi. Dalam UUD NRI 1945 hak-

Sri Soemantri, Prosedur dan Sistem Perubahan Konstitusi (Alumni 2006) 59-60.

Terdapat perbedaan pengertian antara hak asasi manusia (HAM) dan hak warga negara (HAW). HAM pada dasarnya dipahami sebagai hak-hak yang dimiliki manusia bukan karena diberikan kepadanya oleh masyarakat, jadi bukan berdasarkan hukum positif yang berlaku, melainkan berdasarkan martabatnya sebagai manusia. Dengan kata lain bahwa HAM di dasarkan pada faham bahwa secara kondrati manusia itu, dimanapun, mempunyai hak-hak bawaan yang tidak bisa dipindah, diambil dan dialihkan maupun dihilangkan. Sedangkan dalam HAW, hak itu hanya mungkin diperoleh karena seseorang mempunyai status sebagai warga negara. Sedangkan status warga negara tersebut diberikan oleh negara (pemerintah). Jadi HAW ini bukan hak yang melekat pada diri seseorang sebagaimana dalam HAM, melainkan hak yang timbul karena pemberian negara (pemerintah). Moh. Mahfud MD, Demokrasi dan Konstitusi di Indonesia: Studi Tentang Interaksi Politik dan Kehidupan Ketatanegaraan (Rineka Cipta 2003) 165, sebagaimana dikutip oleh Arie Purnomosidi, Negara Hukum Pancasila Tesis, Program Pasca Sarjana Magister Ilmu Hukum Universitas Kristen Satya Wacana, Salatiga 2012) 261.

3 Unsur-unsur dari rechtstaats menurut Julius Stahl adalah: (1) (a) adanya perlindungan terhadap hak asasi manusia; (b) adanya pemisahan kekuasaan (c) pemerintahan berdasarkan pada undangundang; dan (d) adanya peradilan administrasi. Ibid, 186.

$4 \quad$ Unsur-Unsur Rule of Law menurut A.V. Dicey adalah: (1) Supremasi Hukum (supremacy of law); (2) persamaan kedudukan di depan hukum (equality before the law); (3) terjaminnya Hak asasi manusia di dalam Undang-Undang Dasar (Constitution based on human right), Ibid, 93. 
hak yang secara tegas disebut sebagai hak asasi manusia yaitu sebagaimana termuat dalam Bab XA UUD NRI 1945. Hak asasi manusia merupakan hak yang melekat pada harkat dan martabat manusia sejak lahir, seperti hak untuk hidup, hak untuk diperlakukan sama dan hak untuk mendapat kepastian hukum dan keadilan serta sejumlah hak-hak asasi lainnya. Hak asasi tersebut pada hakikatnya dikatakan tidak tergantung pada negara, dan telah ada sebelum negara lahir. ${ }^{5}$

Ruang lingkup manusia sebagaimana dimaksud mencakup siapapun tanpa terkecuali termasuk di dalamnya penyandang disabilitas. Penegasan mengenai lingkup itu sangat penting, karena HAM bagi penyandang disabilitas masih kerap diabaikan, bahkan dilanggar. Pelanggaran terjadi karena penyandang disabilitas tidak dianggap sebagai bagian dari warga negara, bahkan juga tidak dianggap manusia. ${ }^{6}$ Kondisi tersebut mengakibatkan para penyandang disabilitas tidak mendapatkan perlindungan yang layak. Sehingga penyandang disabilitas rentan untuk dijadikan alat produksi yang murah, misalnya menjadi pekerja anak dan buruh perempuan yang selalu dibayangi tindakan pelanggaran HAM. Dalam kondisi itu, penyandang disabilitas rentan terkena tindakan diskriminatif ganda, yaitu ketika seorang penyandang disabilitas merupakan seorang anak, perempuan, dan lanjut usia.

Mengacu pada banyaknya jumlah penyandang disabilitas, semestinya memang tidak terjadi pembedaan perlakuan pemenuhan hak antara orang yang normal dengan penyandang disabilitas. Meskipun demikian, tidak dapat dipungkiri bahwa secara praktis banyak karya mengagumkan yang dihasilkan para penyandang disabilitas. ${ }^{7}$

\section{PEMBAHASAN}

\section{Pengertian Penyandang Disabilitas}

Perlu dijelaskan bahwa dalam tulisan ini, digunakan istilah penyandang disabilitas dibandingkan istilah penyandang cacat. Alasan digunakan istilah penyandang disabilitas dikarenakan istilah penyandang cacat selama ini dipakai dalam menggambarkan sosok anak cucu Adam yang mengalami kelainan fisik dan/ atau mental. ${ }^{8}$ Sehingga istilah pe-

5 Maruarar Siahaan, Hak Konstitusional Dalam UUD 1945,(Salatiga 3 Desember 2011), 6 <http:// lama.elsam.or.id/downloads / 13222798965_HAK_KONSTITUSIONAL_DALAM_UUD_1945> diakses pada tanggal 13 November 2016.

$6 \quad$ Fajri Nursyamsi dkk. Kerangka Hukum Penyandang Disabilitas di Indonesia: Menuju Indonesia Ramah Disabilitas (Pusat Studi Hukum dan Kebijakan Indonesia 2015) 9.

$7 \quad$ Naskah Akademik Rancangan Undang-Undang Tentang Penyandang Disabilitas, (2014), 4. <http:/ /www.dpr.go.id/doksileg/proses1/RJ1-20150701-023052-2614.pdf>. Diakses pada tanggal 20 Februari 2017.

$8 \quad$ Pasal 1 angka Undang-Undang Nomor 4 Tahun 1997 menyebutkan bahwa penyandang cacat adalah setiap orang yang mempunyai kelainan fisik dan/atau mental yang dapat mengganggu atau merupakan rintangan dan hambatan baginya untuk melakukan secara selayaknya yang terdiri dari penyandang cacat fisik, penyandang cacat mental serta penyandang cacat fisik dan mental. 
nyandang cacat tersebut dinilai tidak sejalan dengan prinsip HAM dan merendahkan harkat dan martabat manusia.

Menurut John C. Maxwell, penyandang disabilitas merupakan seseorang yang mempunyai kelainan dan/atau yang dapat mengganggu aktivitas. ${ }^{9}$ Sementara itu, Pasal 1 angka 1 Undang-Undang Nomor 8 Tahun 2016 tentang Penyandang Disabilitas (UU No. 8 Tahun 2016) menyebutkan bahwa penyandang disabilitas adalah setiap orang yang mengalami keterbatasan fisik, intelektual, mental, dan/atau sensorik dalam jangka waktu lama yang dalam berinteraksi dengan lingkungan dapat mengalami hambatan dan kesulitan untuk berpartisipasi secara penuh dan efektif dengan warga negara lainnya berdasarkan kesamaan hak. Dari definisi tersebut, penyandang disabilitas berdasarkan Pasal 4 UU No. 8 Tahun 2016 dapat dikategorikan kedalam empat kelompok, yaitu:

a. Penyandang Disabilitas fisik, yaitu terganggunya fungsi gerak, antara lain amputasi, lumpuh layuh atau kaku, paraplegi, celebral palsy (CP), akibat stroke, akibat kusta, dan orang kecil.

b. Penyandang Disabilitas intelektual, yaitu terganggunya fungsi pikir karena tingkat kecerdasan di bawah rata-rata, antara lain lambat belajar, disabilitas grahita dan down syndrom. c. Penyandang Disabilitas mental, yaitu terganggunya fungsi pikir, emosi, dan perilaku, antara lain:

- psikososial di antaranya skizofrenia, bipolar, depresi, anxietas, dan gangguan kepribadian; dan

- disabilitas perkembangan yang berpengaruh pada kemampuan interaksi sosial di antaranya autis dan hiperaktif.

- Penyandang Disabilitas sensorik, yaitu terganggunya salah satu fungsi dari panca indera, antara lain disabilitas netra, disabilitas rungu, dan/atau disabilitas wicara.

Sementara itu, Organisasi Kesehatan Dunia (WHO atau World Health Organization) memberikan definisi disabilitas sebagai keadaan terbatasnya kemampuan untuk melakukan aktivitas dalam batas-batas yang dianggap normal. Sehingga oleh WHO, terdapat tiga kategori disabili-tas, yaitu:

a. Impairment, yaitu kondisi ketidaknormalan atau hilangnya struk-tur atau fungsi psikologis, atau anatomis;

b. Disability yaitu ketidak mampuan atau keterbatasan sebagai akibat adanya impairment untuk melakukan aktivitas dengan cara yang dianggap normal bagi manusia;

c. Handicap, yaitu keadaan yang merugikan bagi seseorang akibat

\footnotetext{
$9 \quad$ Sugiono, Ilhamuddin, dan Arief Rahmawan, Klasterisasi Mahasiswa Difabel Indonesia Berdasarkan Background Histories dan Studying Performance' (2014) 1 Indonesia Journal of Disability Studies 20, 21.
} 
adanya impairment, disability yang mencegahnya dari pemenuhan peranan yang normal (dalam konteks usia, jenis kelamin, serta faktor budaya) bagi orang yang bersangkutan. ${ }^{10}$

\section{Hak Konstitusional Penyandang Disabilitas di Indonesia}

Penyandang disabilitas adalah anggota masyarakat dan memiliki hak untuk tetap berada dalam komunitas lokal. Para penyandang disabilitas harus menerima dukungan yang dibutuhkan dalam struktur pendidikan, kesehatan, pekerjaan dan pelayanan sosial. Sehingga hak-hak penyandang disabilitas dalam persektif HAM dikategorikan sebagai hak khusus bagi kelompok masyarakat tertentu. ${ }^{11}$

Berbicara tentang hak konstitusional, berarti membicarakan tentang hak dasar manusia yang dimuat dalam konstitusi. Hak konstitusional penyandang disabilitas ini perlu untuk diatur baik dalam konstitusi maupun di dalam undang-undang yang bertujuan bukan hanya untuk menjamin pemenuhan hak dan kebutuhan para penyandang disabilitas, tetapi juga memberikan tanggung jawab pada pemerintah dan masyarakat untuk lebih berperan aktif dalam meningkatkan harkat dan martabat para penyandang disabilitas. Selain itu, penga- turan hak penyandang disabilitas ke dalam konstitusi maupun undangundang diharapkan dapat memperkuat komitmen untuk kemajuan dan perlindungan terhadap hak penyandang disabilitas di Indonesia. Dengan demikian, hak penyandang disabilitas ini akan menjadikannya sebagai hak yang dilindungi secara konstitusional atau hak konstitusional (constitutional rights).

Penyandang disabilitas memiliki hak fundamental layaknya manusia pada umumnya dan penyandang disabilitas memperoleh perlakuan khusus dimaksudkan sebagai upaya perlindungan dari kerentanan terhadap berbagai pelanggaran HAM. Sebagai hak konstitusional, bentuk hukum hak-hak penyandang disabilitas dapat diatur dalam tiga bentuk yaitu: (1) diatur konstitusi, dalam hal ini Pasal 28I ayat (2) UUD NRI 1945; (2) diatur dalam suatu undang-undang berikut sanksi hukuman bagi pelanggarnya (contoh: diatur dalam UndangUndang Nomor 39 Tahun 1999 Tentang Hak Asasi Manusia (UU No. 39 Tahun 1999) dan UU No. 8 Tahun 2016); (3) diatur dalam Peraturan Daerah (contoh: Peraturan Daerah Provinsi Jawa Tengah Nomor 11 Tahun 2014 tentang Pemenuhan Hak Penyandang Disabilitas).

Landasan hak konstitusional yang mengatur perihal perlindungan khusus bagi penyandang disabilitas diatur dalam Pasal 28H ayat (2) jo. Pasal 28I

\footnotetext{
$10 \quad$ Ibid.

11 Terkait dengan hak khusus bagi kelompok masyarakat tertentu, lihat lebih lanjut dalam Bagir Manan dkk., Perkembangan Pemikiran dan Pengaturan Hak Asasi Manusia di Indonesia (PT. Alumni 2006) 140-152.
} 
ayat (2) UUD NRI 1945. Pasal 28H ayat (2) mengatur bahwa, "setiap orang berhak mendapat kemudahan dan perlakuan khusus untuk memperoleh kesempatan dan manfaat yang sama guna mencapai persamaan dan keadilan." Dalam konteks Pasal 28H ayat (2) UUD NRI 1945 diperjelas dengan Pasal 5 ayat (3) jo Pasal 42 ayat (2) UU No. 39 Tahun 1999. Pasal 5 ayat (3) UU No. 39 Tahun 1999 menyebutkan bahwa: "Setiap orang yang termasuk kelompok masyarakat yang rentan berhak memperoleh perlakuan dan perlindungan lebih berkenaan dengan kekhususannya." Pengaturan ini diperkuat oleh Pasal 42 ayat (2) UU No. 39 Tahun 1999 yang mengatur bahwa setiap penyandang cacat, orang yang berusia lanjut, wanita hamil, dan anak-anak, berhak memperoleh kemudahan dan perlakuan khusus.

Dengan pemaknaan di atas, menegaskan bahwa kelompok penyandang disabilitas termasuk dalam terminologi "setiap orang" dalam ketentuan Pasal 28H ayat (2) UUD NRI 1945. Selain itu, dalam penafsiran tersebut juga disebutkan bahwa makna dari "kemudahan" dan "perlakuan khusus" bukanlah dipahami dalam makna perlakuan yang diskriminatif, tetapi tetap dalam lingkup pemenuhan hak konstitusional. Oleh sebab itu, para penyandang disabilitas memiliki keduduk-an, hak dan kewajiban yang sama dengan masyarakat non disabilitas tanpa adanya diskriminasi. Hal ini sebagaimana diatur dalam Pasal 28I ayat (2) UUD 1945 yang mengatur bahwa setiap orang berhak bebas atas perlakuan yang bersifat diskriminatif atas dasar apapun dan berhak mendapatkan perlindungan terhadap perlakuan yang bersifat diskriminatif itu.

Penyandang disabilitas sebagai bagian dari warga negara Indonesia, sudah sepantasnya mendapatkan perlakuan khusus. Setidaknya terdapat dua makna perlakuan khusus, yang pertama perlakuan khusus ini adalah sebagai upaya perlindungan dari kerentanan terhadap berbagai tindakan diskriminasi ${ }^{12}$ dan terutama perlindungan dari berbagai pelanggaran hak asasi manusia. Perlakuan khusus tersebut dipandang sebagai upaya maksimalisasi penghormatan, pemajuan, perlindungan dan pemenuhan hak asasi manusia universal. Sedangkan yang kedua perlakuan khusus disini adalah bentuk keberpihakan kepada penyandang disabilitas berupa perlakuan khusus dan atau perlindungan yang lebih sebagai kompensasi atas disabillitas yang disandangnya demi memperkecil atau menghilangkan dampak disabilitas sehingga memungkinkan untuk menikmati, berperan dan berkontribusi secara optimal, wajar dan bermartabat dalam segala aspek kehidupan

12 Yang dimaksud dengan tindakan diskriminasi disini adalah setiap pembedaan, pengecualian pembatasan, pelecehan, atau pengucilan atas dasar disabilitas yang bermaksud atau berdampak pada pembatasan atau peniadaan pengakuan, penikmatan, atau pelaksanaan hak Penyandang Disabilitas (lihat Pasal 1 angka 3 UU No. 8 Tahun 2016 Tentang Penyandang Disabilitas). 
berbangsa, bernegara dan bermasyarakat. ${ }^{13}$

Dari penjelasan di atas maka UUD NRI 1945 sudah dengan tegas melindungi hak konstitusional penyandang disabilitas dalam konteks "setiap orang" maupun sebagai bagian dari "warga negara". Selain itu, penyandang disabilitas pun dimungkinkan untuk mendapatkan affir-mative action atau hak atas kemudahan dan perlakuan khusus dalam konteks pemenuhan hak konstitusionalnya tersebut. Kedua konsep tersebut harus dipahami dan diresapi dalam pembentukan peraturan perundang-undangan maupun kebijakan sebagai pelaksanaan dari ketentuan dalam UUD NRI 1945. Oleh sebab itu Pasal 28H ayat (2) jo. Pasal 28I ayat (1) UUD NRI 1945 menjadi landasan yuridis bagi UU No. 8 Tahun 2016. Berdasar-kan UU No. 8 Tahun 2016, hak-hak penyandang disabilitas dapat dikategorikan kedalam tiga kategori yaitu:

Pertama, hak penyandang disabilitas. Terkait dengan hak-hak penyandang disabilitas, diatur dalam Pasal 5 ayat (1) UU No. 8 Tahun 2016. Menurut Pasal 5 ayat (1) UU No. 8 Tahun 2016, penyandang disabilitas memiliki 22 (dua puluh dua) hak. Hak-hak tersebut adalah: (1) hak untuk hidup; (2) bebas dari stigma; (3) privasi; (4) keadilan dan perlindungan hukum; (5) pendidikan; (6) pekerjaan, kewirausahaan, dan koperasi; (7) kesehatan; (8) politik; (9) keagamaan; (10) keolah- ragaan; (11) kebudayaan dan pariwisata; (12) kesejahteraan sosial; (13) aksesibilitas; (14) pelayanan publik; (15) perlindungan dari bencana; (16) habilitasi dan rehabilitasi; (17) konsesi; (18) pendataan; (19) hidup secara mandiri dan dilibatkan dalam masyarakat; (20) berekspresi, berkomunikasi, dan memperoleh informasi; (21) berpindah tempat dan kewarganegaraan; (22) bebas dari tindakan diskriminasi, penelantaran, penyiksaan, dan eksploitasi.

Kedua, hak perempuan disabilitas. Hak untuk perempuan penyandang disabilitas diatur dalam Pasal 5 ayat (1) dan (2) UU No. 8 Tahun 2016. Menurut Pasal tersebut, perempuan penyandang disabilitas memiliki 26 (dua puluh enam) hak. Bagi perempuan penyandang disabilitas, selain 22 (duapuluh dua) hak penyandang disabilitas sebagaimana diatur dalam Pasal 5 ayat (1) UU No. 8 Tahun 2016, juga memiliki hak:

a. atas kesehatan reproduksi;

b. menerima atau menolak penggunaan alat kontrasepsi;

c. mendapatkan Perlindungan lebih dari perlakuan Diskriminasi berlapis; dan

d. untuk mendapatkan Perlindung-an lebih dari tindak kekerasan, termasuk kekerasan dan eksploi-tasi seksual.

Ketiga, hak anak disabiltas. Adapun, anak penyandang disabilitas memiliki 29 (duapuluh sembilan) jenis

13 Badan Pembinaan Hukum Nasional (BPHN), Naskah Akademik RUU Disabilitas (BPHN 2015) 45. 
hak. Selain hak sebagaimana dimaksud pada Pasal 5 ayat (1) UU No. 8 Tahun 2016, anak penyandang disabilitas juga memiliki hak untuk:

a. mendapatkan perlindungan khusus dari diskriminasi, penelantaran, pelecehan, eksploitasi, serta kekerasan dan kejahatan seksual;

b. mendapatkan perawatan dan pengasuhan keluarga atau keluarga pengganti untuk tumbuh kembang secara optimal;

c. dilindungi kepentingannya dalam pengambilan keputusan;

d. perlakuan anak secara manusiawi sesuai dengan martabat dan hak anak;

e. pemenuhan kebutuhan khusus;

f. perlakuan yang sama dengan anak lain untuk mencapai integrasi sosial dan pengembangan individu; dan

g. mendapatkan pendampingan sosial.

\section{Konsep Perlindungan Hak Kons- titusional Penyandang Disabilitas}

Pada hakikatnya Tuhan menciptakan manusia di dunia ini adalah sama, namun manusia itu sendirilah yang membedakan di antara sesama manusia, baik berwujud sikap, perilaku, maupun perlakuannya. Pembedaan ini masih sangat dirasakan oleh mereka yang mengalami keterbatasan secara fisik, mental, dan fisik-mental, baik sejak lahir maupun setelah dewasa, dan kecacatan tersebut tentunya tidak diharapkan oleh semua manusia, baik yang menyan-dang disabilitas maupun yang tidak menyandang disabilitas. ${ }^{14}$

Selain itu, permasalahan mendasar bagi penyandang disabilitas adalah kurangnya pemahaman masyarakat maupun aparatur pemerintah yang terkait arti disabilitas dan keberadaan penyandang disabilitas sebagai bagian dari warga negara. Adanya anggapan bahwa disabilitas merupakan aib, kutukan dan memalukan membuat keluarga menjadi tidak terbuka mengenai anggota keluarganya yang memiliki disabilitas. Penyandang disabilitas disamakan dengan orang sakit dan tidak berdaya sehingga tidak perlu diberikan pendidikan dan pekerjaan. Mereka cukup dikasihani dan diasuh untuk kelangsungan hidupnya. Sehingga hal tersebut mengakibatkan penyandang disabilitas tidak mendapat hak dan kesempatan yang sama seperti warga masyarakat lainnya.

Hal tersebut mengakibatkan para penyandang disabilitas tidak mendapatkan perlindungan yang layak. Sehingga penyandang disabilitas rentan untuk dijadikan alat produksi yang murah, misalnya menjadi pekerja anak dan buruh perempuan yang selalu dibayangi tindakan pelanggaran HAM. Dalam kondisi itu, penyandang disabilitas rentan terkena tindakan diskriminatif ganda, yaitu ketika seorang penyandang disabilitas merupakan seorang anak, perempuan,

14 Tjepy F. Aloewie, 'Kesetaraan dan Kesempatan Kerja Bagi Tenaga Kerja Penyandang Cacat' (Temu Konsultasi Penanganan Penyandang Cacat bagi Orsos, Jakarta 2000). 
dan lanjut usia. Oleh karena itu, kehidupan kelompok tersebut jauh lebih sulit. ${ }^{15}$

Salah satu cara untuk meminimalisir diskriminasi terhadap penyandang disabilitas adalah dengan cara memberikan perlindungan secara penuh dan setara. Hal ini sebagaimana diatur dalam Pasal 3 huruf a UU No. 8 Tahun 2016 yaitu untuk mewujudkan penghormatan, pemajuan, perlindungan, dan pemenuhan hak asasi manusia serta kebebasan dasar penyandang disabilitas secara penuh dan setara. Maksud dengan setara disini adalah menempatkan penyandang disabilitas setara atau sejajar dengan orang non disabilitas atau dengan istilah memanusiakan manusia (memanusiakan penyandang disabilitas). ${ }^{16}$ Sehingga dalam konsep memanusiakan penyandang disabilitas, negara wajib menghormati, menghargai, memenuhi dan memberikan perlindungan bagi setiap warga negaranya tanpa terkecuali (termasuk penyandang disabilitas).
Perlindungan penyandang disabilitas diartikan untuk menggambarkan perlindungan hukum ${ }^{17}$ yang diberikan kepada penyandang disabilitas dalam usahanya untuk memenuhi kebutuhannya dari hal-hal yang dapat merugikan penyandang disabilitas itu sendiri. Pada akhirnya, perlindungan ini juga dapat diartikan sebagai pengakuan bahwa diskriminasi berdasarkan disabilitas merupakan pelanggaran terhadap martabat dan nilai yang melekat pada setiap orang. Di samping itu, perlindungan penyandang disabilitas juga dapat diartikan sebagai upaya menciptakan lingkungan dan fasilitas umum yang aksesibelitas demi kesamaan kesempatan bagi penyandang disabilitas untuk hidup mandiri dan bermasyarakat. ${ }^{18}$

Setidaknya terdapat tiga aspek perlindungan terhadap penyandang disabilitas, yaitu pertama, aspek filosofis. Ditinjau dari aspek filosofis, perlindungan terhadap penyandang disabilitas diperlukan untuk peme-

15 Fajri Nursyamsi, Op.Cit. 19.

16 Terkait dengan memanusiakan manusia lihat Teguh Prasetyo, Teori Keadilan Bermartabat (Nusa Media 2016).

17 Berdasarkan Pasal 9 UU No. 8 Tahun 2016, hak perlindungan hukum untuk Penyandang Disabilitas meliputi hak: a. atas perlakuan yang sama di hadapan hukum; b. diakui sebagai subjek hukum; c.memiliki dan mewarisi harta bergerak atau tidak bergerak; d.mengendalikan masalah keuangan atau menunjuk orang untuk mewakili kepentingannya dalam urusan keuangan; e.memperoleh akses terhadap pelayanan jasa perbankan dan nonperbankan; f.memperoleh penyediaan Aksesibilitas dalam pelayanan peradilan; g. atas Pelindungan dari segala tekanan, kekerasan, penganiayaan, Diskriminasi, dan/atau perampasan atau pengambil alihan hak milik; h.memilih dan menunjuk orang untuk mewakili kepentingannya dalam hal keperdataan di dalam dan di luar pengadilan; dan i. dilindungi hak kekayaan intelektualnya. 
nuhan harkat dan martabat sebagai manusia. Hal mana penyandang disabilitas wajib diperlakukan secara manusiawi sesuai dan sederajat dengan manusia normal. Sesuai dengan falsafah Pancasila bahwa setiap orang (termasuk penyandang disabilitas) memiliki kesempatan yang sama baik dalam hal pekerjaan, mengakses fasilitas umum, mendapatkan kehidupan dan penghidupan yang layak.

Kedua, aspek yuridis. Ditinjau dari aspek yuridis, bahwa untuk menjamin pelindungan khusus terhadap hak dan kedudukan, serta pelindungan dari perlakuan diskriminatif bagi penyandang disabilitas, diperlukan instrumen hukum yang secara khusus pula mengatur mengenai penyandang disabilitas. Jaminan dan perlindungan terhadap hak dan kedudukan yang setara serta jaminan pelindungan dari perlakuan diskriminatif bagi penyandang disabilitas dalam segala aspek kehidupan. Jaminan dan perlindungan negara tersebut telah dinyatakan dalam Pasal $28 \mathrm{H}$ ayat (2) UUD NRI 1945 yang menyebutkan bahwa: "Setiap orang berhak mendapat kemudahan dan perlakukan khusus untuk memperoleh kesempatan dan manfaat yang sama guna mencapai persamaan dan keadilan". Selanjutnya juga ditegaskan dalam Pasal 28I ayat (2) UUD NRI 1945 bahwa: "Setiap orang bebas dari perlakuan yang bersifat diskriminatif atas dasar apapun dan berhak men-dapatkan perlindungan terhadap per-lakuan yang bersifat diskriminatif itu". ${ }^{19}$

Ketiga aspek sosiologis. Dari aspek sosiologis, perlindungan terhadap penyandang disabilitas sejalan dengan prinsip keadilan sosial yang merupakan nilai dasar bernegara di Indonesia. Bahkan upaya perlindungan saja belumlah memadai dengan pertimbangan bahwa jumlah penyandang disabilitas akan meningkat pada masa yang akan datang, masih diperlukan lagi sarana dan upaya lain terutama dengan penyediaan sarana untuk memperoleh kesamaan kesempatan bagi penyandang disabilitas dalam segala aspek kehidupan dan penghidupan, khususnya dalam memperoleh pendidikan dan pekerjaan dalam rangka mewujudkan kesejahteraan sosial. ${ }^{20}$

Pengaturan mengenai hak-hak penyandang disabilitas tersebut membawa konsekuensi hukum bagi negara maupun masyarakat. Ditinjau dari sisi masyarakat, masyakarat terikat dan mempunyai kewajiban untuk menghormati hak-hak penyandang disabilitas. Hal ini sebagaimana diamanatkan oleh Pasal 28J ayat (1) UUD NRI 1945 yang menyebutkan bahwa setiap orang wajib menghormati hak asasi manusia orang lain dalam tertib kehidupan bermasyarakat, berbangsa dan bernegara. Pasal $28 \mathrm{~J}$ ayat (1) diperkuat

\footnotetext{
$18 \quad$ Zulkarnain Ridwan, 'Perlindungan Hak-Hak Konstitusional Penyandang Disabilitas (Rights of Persons With Disabilities)' (2013) 7 Fiat Justisia Jurnal Ilmu Hukum 231, 237-238.

19 BPHN, Op.Cit. 145.

$20 \quad$ Ibid. 234-235.
} 
oleh Pasal 69 UU No. 39 Tahun 1999 yang menyatakan bahwa:

(1) Setiap orang wajib menghormati hak asasi manusia orang lain, moral, etika, dan tata tertib kehidupan bermasyarakat, berbangsa, dan bernegara.

(2) Setiap hak asasi manusia seseorang menimbulkan kewajiban dasar dan tanggung jawab untuk menghormati hak asasi orang lain secara timbal balik serta menjadi tugas Pemerintah untuk menghormati, melindungi, menegakkan, dan memajukannya.

Sementara itu, konsekuensi bagi negara adalah adanya kewajiban bagi Negara untuk melindungi (the obligation to protect) dan memenuhi (the obligation to fulfill) hak para penyandang disabilitas. Kewajiban disini tidak hanya terfokus pada upaya perlindungan dari pelanggaraan yang dilakukan negara, namun juga terhadap pelanggaran atau tindakan yang dilakukan oleh entitas atau pihak lain (nonnegara) yang akan mengganggu perlindungan hak penyandang disabilitas. Termasuk dalam hal ini adalah perlindungan yang dilakukan oleh negara untuk menghindarkan penyandang disabilitas dari ancaman kesia-siaan, pelantaran atau eksploitasi dan lainlain. Sedangkan kewajiban untuk memenuhi (the obligation to fulfill) adalah kewajiban negara untuk mengambil langkah-langkah legislatif, administratif, yudisial dan praktis, yang perlu dilakukan untuk meme21 BPHN, Op.Cit. 39. nuhi hak penyandang disabilitas yang dijamin oleh konstitusi maupun peraturan perundang-undangan, dalam hal ini negara wajib menyediakan berbagai fasilitas fisik dan non fisik khususnya jaminan pemeliharaan dan kesejahteraan secara permanen kepada penyandang disabilitas dari kalangan kategori berat. ${ }^{21}$

Hingga saat ini sarana dan upaya untuk memberikan perlindungan hukum terhadap kedudukan, hak, kewajiban, dan peran penyandang disabilitas telah diberikan melalui berbagai peraturan perundang-undangan, antara lain yaitu:

1. Undang-Undang Nomor 13 Tahun 2003 tentang Ketenagakerjaan (UU No. 13 Tahun 2003). Di dalam Pasal 67 UU No. 13 Tahun 2003 diatur bahwa pengusaha yang mempekerjakan penyandang cacat wajib memberikan perlindungan sesuai dengan jenis dan derajat kecacatannya. Yang dimaksud perlindungan disini adalah penyediaan aksesibilitas, pemberian alat kerja dan alat pelindung diri yang sesuai dengan jenis dan derajat kecacatannya.

2. Undang-Undang Nomor 36 Tahun 2009 tentang Kesehatan (UU No. 36 Tahun 2009). Perlindungan terhadap penyandang disabilitas dibidang kesehatan berupa Upaya pemeliharaan kesehatan penyandang cacat harus ditujukan untuk menjaga agar tetap hidup sehat dan produktif secara sosial, ekonomis, 
dan bermartabat (Pasal 136 UU No. 36 Tahun 2009).

Dalam upaya perlindungan dan pemenuhan hak penyandang disabilitas tersebut, negara harus mengacu pada prinsip-prinsip umum berikut, yaitu:

1. Penghormatan pada martabat yang melekat, otonomi individual, termasuk kebebasan untuk menentukan pilihan, dan kemerdekaan perseorangan;

2. Non diskriminasi;

3. Partisipasi penuh dan efektif dan keikutsertaan dalam masyarakat;

4. Penghormatan atas perbedaan dan penerimaan penyandang disabilitas sebagai bagian dari keragaman manusia dan kemanusiaan;

5. Kesetaraan kesempatan;

6. Aksebilitas;

7. Kesetaraan antara laki-laki dan perempuan. ${ }^{22}$

\section{PENUTUP}

Pentingnya penekanan perlindungan hak bagi penyandang disabilitas dikarenakan penyandang disabilitas merupakan orang-orang yang berkemampuan khusus, sehingga perlu perlakuan yang khusus juga dari pemerintah untuk memenuhi hak-hak yang disebutkan dalam Bab XA UUD NRI 1945 mengenai hak asasi manusia. Selain itu tanpa adanya perlindungan lebih dari Pemerintah, para kaum penyandang disabilitas ini rentan terhadap perlakuan diskriminasi, terlebih terhadap pemenuhan hak-haknya.

\section{DAFTAR BACAAN}

Aloewie, Tjepy F., 'Kesetaraan dan Kesempatan Kerja Bagi Tenaga Kerja Penyandang Cacat' (Temu Konsultasi Penanganan Penyandang Cacat bagi Orsos, Jakarta 2000).

Badan Pembinaan Hukum Nasional (BPHN) Naskah Akademik UndangUndang Penyandang Disabilitas (BPHN 2015).

Manan, Bagir, dkk, Perkembangan Pemikiran dan Pengaturan Hak Asasi Manusia di Indonesia (PT. Alumni 2006).

Mahfud MD, Moh, Demokrasi dan Konstitusi di Indonesia: Studi Tentang Interaksi Politik dan Kehidupan Ketatanegaraan (Rineka Cipta 2003).

Naskah Akademik Rancangan UndangUndang Tentang Penyandang Disabilitas, (2014), <http://www. dpr.go.id/doksileg/proses $1 /$ RJ 120150701-023052-2614.pdf > . Diakses pada tanggal 20 Februari 2017.

Nursyamsi, Fajri, dkk, Kerangka Hukum Disabilitas di Indonesia: Menuju Indonesia Ramah Disabilitas (Pusat Studi Hukum dan Kebijakan Indonesia 2015).

$22 \quad$ Rahayu Repindowaty dan Bustanuddin, 'Perlindungan Hukum Terhadap Penyandang Disabilitas Menurut Convention on the Rights of Persons with Disabilities (CRPD)' (2015) VIII Jurnal Inovatif 17, 26. 
Prasetyo, Teguh, Teori Keadilan Bermartabat (Nusa Media 2016).

Purnomosidi, Arie, Negara Hukum Pancasila (Tesis, Universitas Kristen Satya Wacana 2012).

Repindowaty, Rahayu, dan Bustanuddin, Perlindungan Hukum Terhadap Penyandang Disabilitas Menurut Convention on the Rights of Persons with Disabilities (CRPD)' (2015) VIII Jurnal Inovatif 17.

Ridwan, Zulkarnain, 'Perlindungan Hak-Hak Konstitusional Penyandang Disabilitas (Rights of Persons With Disabilities)' (2013) 7 Fiat Justisia Jurnal Imu Hukum 231.

Siahaan, Maruarar, Hak Konstitusional Dalam UUD 1945, (Salatiga 3 Desember 2011), 6 <http://lama. e $1 \mathrm{sam}$. or.id / d own 1 oads / $13222798965_{-} \mathrm{HAK}_{-}$KON S TITUSIONAL_DALAM_UUD_1945> diakses pada tanggal 13 November 2016.

Soemantri, Sri, Prosedur dan Sistem Perubahan Konstitusi, Edisi Kedua, (Alumni 2006).

Sugiono, Ilhamuddin, dan Arief Rahmawan,'Klasterisasi Mahasiswa Difabel Indonesia Berdasarkan Background Histories dan Studying Performance' (2014) 1 Indonesia Journal of Disability Studies 20.

Undang-Undang Dasar Negara Republik Indonesia Tahun 1945.

Undang-Undang Nomor 4 Tahun 1997 Tentang Penyandang Cacat.
Undang-Undang Nomor 39 Tahun 1999 Tentang Hak Asasi Manusia. Undang-Undang Nomor 8 Tahun 2016 Tentang Penyandang Disabilitas. 
[Vol. 1, No. 2 